\title{
The Implementation Challenges of Zero Carbon and Zero Waste Approaches
}

\author{
L. Švecová ${ }^{1, *}, G$. Ostapenko ${ }^{1}, J$. Veber ${ }^{1}$, and $Y$. Valeeva ${ }^{2}$ \\ ${ }^{1}$ Masaryk Institute of Advanced Studies Czech Technical University in Prague, Prague, Czech Republic \\ ${ }^{2}$ Kazan State Power Engineering University, Kazan, Russia
}

\begin{abstract}
The paper discusses the implementation challenges of approaches with zero carbon emissions and zero waste. Based on the analysis of world statistics of energy sources, environmental policies and plans in the field of decarbonisation and application of renewable energy, the authors highlight challenges and barriers which can be faced during implementation of such plans in the indicated time horizon. Various levels of readiness of countries and global energy players to reduce fossil fuels in energy mix are listed among the main barriers. The paper shows other ways of energy saving, focusing at implementation of circular economy. Based on the results of the Czech Republic experience in the field of circular economy it is identified, that it is slowly embracing the zero waste approach. However, awareness of people and practical applications of new concept of zero waste circular economy are low in business and among the young generation. The practical implication of findings and some recommendations to environmental education and governments are introduced.
\end{abstract}

\section{Introduction}

The overall outcome from human activities since the Industrial Revolution is a warming effect, driven primarily by emissions of carbon dioxide and enhanced by emissions of other greenhouse gases. In this context, the challenge today is how to survive on Earth in scenario of its unprecedented economic development with increasing demand in energy and the global warming processes. Scientists warn that if they do not make substantial changes in order to keep global temperature rises below $1.5{ }^{\circ} \mathrm{C}$, the results will be disastrous. Decarbonizing the power sector while meeting the rapidly expanding demand for power, particularly in the developing world, is probably the most important challenge facing the global energy system over the next 20 years [1].

Every country has unique circumstances in creating long-term, lowest emission strategies, depending on various sources of energy, absolute and comparative advantages in production and consumption of energy, the level of energy development and its governance. That is why the worry about long-term environmental sustainability in practice could be overshadowed by more immediate concerns about energy accessibility, its cost and affordability. "There will always be those who value short-term economic growth over long-term climate benefits" [2, p.334].

Creating long-term, lowest-emissions strategies, shaped to each country's unique circumstances, is crucial to maintaining growth while reducing emissions. The sixth Global Environment Outlook [3] in 2019 calls on decision makers to take immediate actions to address pressing environmental issues to achieve the Sustainable Development Goals as well as other Internationally Agreed Environment Goals, such as the Paris Agreement. The agreement seeks to keep temperatures to 1.5 degree or at the very least to "well below 2 degrees" above pre-industrial levels [4].

The European Union has become a world leader in environmental protection in their intention to develop renewable, low-carbon or "zero carbon" approaches as well as zero waste circular economy. The most optimistic aim of "zero carbon", namely reducing emissions from combustion to zero by 2050 , has been redesigned at the Council of the EU in June this year [5]. These intentions are also accompanied by comprehensive approaches, namely the Plastics Strategy, the Circular Economy Action Plan and the revised waste legislation. As climate change economist Nicholas Stern noted, "Recycling is already making a major contribution to keeping down emissions. Indeed, its scale is so little appreciated that it might be described as one of the 'best kept secrets' in energy and climate change" [6].

Based on world statistical information and researcher opinions towards the situation in the world in the context of the climate crisis, we present below some analytical results, which highlight the challenging issues and barriers for decarbonization and fulfilment the zero emissions and zero waste plans by 2050 , concluding that such plans could be achieved with certain assumptions.

\footnotetext{
*Corresponding author: lenka.svecova@cvut.cz
} 


\section{The Challenges of Zero Carbon Plan Implementation}

At the end of the 19th century Swedish scientist Svante Archenius began to study the $\mathrm{CO}_{2}$ impact on climate. In the 1960s, David Keeling demonstrated that humancaused carbon dioxide emissions are large enough to cause global warming [7]. The levels of carbon dioxide in the atmosphere today are higher than they were at any time in the past 3-5 million years. In 2016, carbon dioxide officially passed the symbolic $400 \mathrm{ppm}$ mark, and, according to scientists, will never return below it in our lifetimes [8]. The latest dates approved the assumptions of scientists. According to the World Meteorological Organization (WMO), which published the state of the global climate every year, the carbon dioxide levels in atmosphere are the following: 403.3 ppm was in 2016; 405.5 ppm was in 2017; $411.7 \mathrm{ppm}$ was in 2018 [9]. The latest up-to-date climate-related data and opinions were brought by the 24th United Nations World Climate Conference, held in Katowice in the first half of December 2018 [10]. The analytical materials presented at the conference showed that $\mathrm{CO}_{2}$ emissions increased in 2018 and it was the largest increase for seven years [10]. The problem is that "the longer carbon emissions continue to rise, the harder and costlier will be the eventual adjustment to net zero carbon emissions" [11, p. 23].

Net zero means that the amount of greenhouse gases emitted into the atmosphere is not more than the amount which is taken out. According to the European Commission 2050 Long-Term Strategy, Climate Action "net zero target means that almost all emissions have to be cut. Fossil fuels should be phased out, diesel and petrol cars should be replaced by electric vehicles, and meat consumption must be slashed" [5]. There are challenging issues with that implementation. Barriers are not only technological and economical (when in some industries, such as in agriculture, it is very difficult to get rid of emissions, or in aviation and shipping, where lowcarbon alternatives don't exist yet), but mostly political and social. The European Union has failed to set a firm deadline to end its contribution to climate change, after a group of central and eastern European countries blocked a proposal to slash EU carbon emissions to net zero by 2050. The EU proposal to slash carbon emissions to net zero by 2050 was blocked by four countries: Poland, the Czech Republic, Hungary and Estonia. Some countries, including Sweden and the UK have set their own independent net zero emission targets [12].

In reality only several countries have so far passed laws that will require them to cut emissions to net zero. The Energy and Climate Intelligence Unit (ECIU) report designated a number of nations that make any substantial moves towards meeting the pledge, though they have all joined the Carbon Neutrality Coalition, an international body that pledges to meet net zero targets. This includes the following countries: Canada, Colombia, Ethiopia, Germany, Sweden, Luxembourg, Mexico and the Netherlands. Some countries, including Sweden and the UK have set their own independent net zero emission targets. Japan, meanwhile, has only committed to achieve net zero in the latter half of this century [13].

The World Energy Outlook 2018 examines future patterns of a changing global energy system at a time of increasing uncertainties and finds that major transformations are underway for the global energy sector, from growing electrification to the expansion of renewables, upheavals in oil production and globalisation of natural gas markets. Oil markets, for instance, are entering a period of renewed uncertainty and volatility, including a possible supply gap in the early 2020s [14]. According to McKinsey Global Energy perspective, Global energy related emissions will peak in 2024 and decline by around $20 \%$ by 2050 , mostly driven by the decline of coal usage in the power sector. This downward trajectory, however, is still far off from a 2degree pathway [15]. In order to meet climate targets and avoid dangerous climate change, the world needs a significant and concerted transition in its energy sources.

\subsection{The world situation in energy sources and their use}

In response to the decarbonization challenge, different countries and regions have evolved different mixes of energy sources. The structure of world energy sources is shown in Table 1. We choose the selected key global energy players regarding the main energy sources (renewable and non-renewable energy) they produced in absolute volume of production of the relevant source and its share in the world production. Energy resources are not equally distributed globally. As we can see from the table 1 only the US and China use all energy sources in their energy mix.

It is logical that for many countries and giant corporations focusing on the extraction, processing and distribution of fossil fuels, there is no desirable trend to reduce them in the energy mix. For example, France is heavily invested in nuclear power, while China, despite diversifying in recent years, is still largely dependent on coal. Coal-fired power generation continues to be the single largest emitter, accounting for $30 \%$ of all energyrelated carbon dioxide emissions. China, India, and the United States accounted for $85 \%$ of the net increase in emissions, while emissions declined for Germany, Japan, Mexico, France and the United Kingdom [15]. Coalfired power generation continues to be the single largest emitter, accounting for $30 \%$ of all energy-related carbon dioxide emissions. China, India, and the United States accounted for $85 \%$ of the net increase in emissions, while emissions declined for Germany, Japan, Mexico, France and the United Kingdom [15]. Saudi Arabia has about a fifth of the world's oil reserves, oil revenues make up about $45 \%$ of GDP and $75 \%$ of state revenue, the United Arab Emirates economy is $85 \%$ based on oil and gas extraction and processing.

Russia is gaining up to $40 \%$ of its revenue from oil and gas exports. Norway, after the Middle East, is the largest per capita oil miner and the world's fifteenth largest oil producer, with oil sector accounting for about a quarter of GDP. 
Table 1.

\begin{tabular}{|c|c|c|c|c|c|c|c|c|c|c|c|c|c|c|}
\hline Producers & $\begin{array}{c}\text { MT } \\
\text { oil }\end{array}$ & $\%$ & $\begin{array}{l}\text { cm } \\
\text { gas }\end{array}$ & $\%$ & $\begin{array}{l}\text { Coal } \\
\text { MT }\end{array}$ & $\%$ & $\begin{array}{c}\text { NE } \\
\text { TWh }\end{array}$ & $\%$ & $\begin{array}{l}\text { HEP } \\
\text { TWh }\end{array}$ & $\%$ & $\begin{array}{l}\text { WEP } \\
\text { TWh }\end{array}$ & $\%$ & SEP & $\%$ \\
\hline $\begin{array}{l}\text { United } \\
\text { States }\end{array}$ & 563 & 12.9 & 760 & 20.2 & 702 & 9.3 & 840 & 32.2 & 292 & 7.0 & 229 & 24.0 & 47 & 14.2 \\
\hline $\begin{array}{c}\text { Saudi } \\
\text { Arabia }\end{array}$ & 560 & 12.8 & 94 & 2.5 & & & & & & & & & & \\
\hline Russia & 548 & 12.6 & 694 & 18.4 & 387 & 5.1 & 197 & 7.6 & 187 & 4.5 & & & & \\
\hline Canada & 237 & 5.4 & 184 & 4.9 & & & 101 & 3.9 & 387 & 9.3 & 31 & 3.2 & & \\
\hline Iran & 229 & 5.2 & 214 & 5.7 & & & & & & & & & & \\
\hline Iraq & 225 & 5.2 & & & & & & & & & & & & \\
\hline China & 192 & 4.4 & 142 & 3.8 & 3376 & 44.7 & 213 & 8.2 & 1193 & 28.6 & 237 & 24.8 & 75 & 22.9 \\
\hline $\begin{array}{c}\text { United } \\
\text { Arab } \\
\text { Emirates }\end{array}$ & 178 & 4.1 & & & & & & & & & & & & \\
\hline Kuwait & 149 & 3.4 & & & & & & & & & & & & \\
\hline Brazil & 137 & 3.1 & & & & & & & 381 & 9.1 & 33 & 3.5 & & \\
\hline Norway & & & 128 & 3.4 & & & & & 144 & 3.5 & & & & \\
\hline India & & & & & 730 & 9.7 & & & 138 & 3.3 & 45 & 4.7 & 14 & 4.3 \\
\hline Australia & & & & & 501 & 6.6 & & & & & & & 6 & 1.9 \\
\hline France & & & & & & & 403 & 15.5 & & & 21 & 2.2 & 8 & 2.5 \\
\hline Germany & & & & & 175 & 2.3 & 85 & 3.3 & & & 79 & 8.2 & 38 & 11.6 \\
\hline Korea & & & & & & & 162 & 6.2 & & & & & & \\
\hline World & 4365 & 100 & 3768 & 100 & 7549 & 100 & 2606 & 100 & 4170 & 100 & 958 & 100 & 328 & 100 \\
\hline
\end{tabular}

Source: Authors compilation on the basic of https://www.iea.org/statistics/

Germany's efforts for self-sufficiency and a shift away from nuclear energy (up to 2022) and fossil fuels (up to 2039) (Energiewende) cannot be overlooked. Germany, an early investor in clean energy, turned to renewables. Unlike Japan, Germany hasn't seen a major increase in its share of fossil fuels as it shuts down its nuclear fleet ahead of Chancellor Angela Merkel's 2022 deadline. But phasing out nuclear energy means that Germany's carbon emissions have stayed steady, even as the country rapidly turns to renewables.

A recent EU decision sets 2025 as the target date for ending state aid to high-emission power plants, effectively eliminating subsidies to coal. At the same time, the oil and gas sector continues to benefit from government incentives in several countries, mostly through tax provisions that provide preferential treatment for cost recovery. Such policies could go against domestic efforts to reduce global greenhouse gas emissions [16].

\subsection{Renewable energy in reducing the burning of fossil fuels}

Indeed, renewables should play a decisive role in reducing the burning of fossil fuels. Countries and companies are driving the world in a more climatefriendly direction. Major investors are increasingly moving away from fossil fuel investments towards renewables. Companies like Ikea, Apple, and Facebook have declared that they will only buy renewable power. In spite of high growth in renewable energy, fossil fuel continues to account for 80 per cent of global energy consumption. As David Hone (Chief Climate Change Advisor at Shell) noticed "While we seek to enhance our operations' average energy intensity through both the development of new projects and divestments, we have no immediate plans to move to a net-zero emissions portfolio over our investment horizon of 10-20 years" [17].

The situation in the EU from the point of view of the application of renewable sources in the structure of all energy sources is presented in Table 2. The value (indicator) measures the share of renewable energy consumption in gross final energy consumption according to the Renewable Energy Directive. The gross final energy consumption is the energy used by endconsumers (final energy consumption) plus grid losses and self-consumption of power plants.

It is seen from table 2 that the Nordic countries show very good results, but this is mainly due to favorable natural conditions, which allow the production of electricity in hydroelectric power stations. Other EU countries use a combination of renewable sources in the structure: in Austria hydro and wind energy sources are prevailed, in Denmark it is wind energy, in the Czech Republic hydro and solar sources of energy are dominated. Germany, an early investor in clean energy, turned to renewables. Unlike Japan, Germany hasn't seen a major increase in its share of fossil fuels as it shuts down its nuclear fleet ahead of Chancellor Angela Merkel's 2022 deadline. But phasing out nuclear energy means that Germany's carbon emissions have stayed steady, even as the country rapidly turns to renewables. The 2018 Energy Strategy raised the strategic target of $32 \%$ for renewable energy in total energy production in 2030 and $32.5 \%$ for energy efficiency, but this target is not binding. 
Table 2. Share of renewable energy in gross final energy consumption by countries (annual, per year 2017).

\begin{tabular}{|c|c|c|c|c|c|c|c|c|}
\hline \multirow[t]{2}{*}{ Country/Percentage } & \multicolumn{8}{|c|}{ Values } \\
\hline & $10 \%$ & $20 \%$ & $30 \%$ & $40 \%$ & $50 \%$ & $60 \%$ & $70 \%$ & $80 \%$ \\
\hline \multicolumn{9}{|l|}{ Iceland/71.571 } \\
\hline \multicolumn{9}{|l|}{ Norway/71.177 } \\
\hline \multicolumn{9}{|l|}{ Sweden/54.499 } \\
\hline \multicolumn{9}{|l|}{ Finland/41.009 } \\
\hline \multicolumn{9}{|l|}{ Latvia/39.010 } \\
\hline \multicolumn{9}{|l|}{ Denmark/35.772 } \\
\hline \multicolumn{9}{|l|}{ Austria $/ 32.558$} \\
\hline \multicolumn{9}{|l|}{ Portugal/28.115 } \\
\hline \multicolumn{9}{|l|}{ Romania/24.468 } \\
\hline \multicolumn{9}{|l|}{ Italy/18.267 } \\
\hline \multicolumn{9}{|l|}{ Spain/17.511 } \\
\hline \multicolumn{9}{|l|}{ France/16.30 } \\
\hline \multicolumn{9}{|l|}{ Germany/15.452 } \\
\hline \multicolumn{9}{|l|}{ Czechia/14.760 } \\
\hline Slovakia/11.490 & & & & & & & & \\
\hline
\end{tabular}

Source: Authors' elaboration from Eurostat data browser, 2017 [19]

The EU Energy Efficiency Directive [18] first summarizes the development of strategic goals over the past decade and specifies sub-paths to help energy saving and enhance energy efficiency through savings in energy transmission and distribution, increased energy efficiency in buildings (renovation), accessibility of lowenergy transport, application of efficient water and waste management, cycling. On 28 November 2018, the Commission presented its strategic long-term vision for a prosperous, modern, competitive and climate-neutral economy by 2050 - A Clean Planet for All. The road to a climate neutral economy would require joint action in seven strategic areas, where energy efficiency, deployment of renewables and circular economy are of the highest priority.

\section{Challenges of zero- waste circular economy approach implementation}

A circular economy (CE) is a regenerative system in which resource input and waste, emission, and energy leakage are minimized by slowing, closing, and narrowing energy and material loops. This can be achieved through long-lasting design, maintenance, repair, reuse, remanufacturing, composting, biogas usage, consumption transformation, and recycling. $\mathrm{CE}$ is associated with a variety of concepts, including industrial ecology, waste management, cradle to cradle as relatively new one approach. Ideally, CE implementation is based on a zero-waste approach or movement to have a society that does not produce any waste because everything is recyclable and everything can be used again. However, is this, in fact is it achievable assumption today and in nearest future? Our world is only $9 \%$ circular and the trend is negative [20]. A fully circular economy will reduce our greenhouse gas emissions by more than 60 percent at the WRF, the argument went like this: "if climate change is the inconvenient truth, the potential of the circular economy as an enabler for carbon emission reduction is the overlooked truth" [21]. Most governments consider circular economy measures in policies aimed at meeting the Paris Agreement target of limiting global warming to as close as possible to $1.5^{\circ} \mathrm{C}$. The circular economy is the subject of great attention in EU programmes and set of documents, such as EU Circular Economy Package [8]. So far, steps have been taken by the EU, such as prohibiting the use of plastic trays, cutlery, beverage cups. All plastic packaging on the EU market will be recyclable by 2030 , the consumption of single-use plastics will be reduced and the intentional use of microplastics will be restricted [22]. This intention is gradually being put into practice, and the majority of European residents have no problem with it. While CE has become a part of the government programs in the Czech Republic, however it is still a bit behind the most developed European countries. Our recent study about the CE implementation in Czech Republic enterprises practices confirmed that there are eco-innovative companies introducing the creative environmental, ecological and social responsible solutions, but the examples are still limited. The findings revealed that $\mathrm{CE}$ in Czech Republic is implemented mostly with "bottom - up" approach i.e. from the level of several business entities and non-governmental institutions. We assumed that the reasons of slow implementation of a new $\mathrm{CE}$ 
concept are the barriers primarily cultural and social, but not only technological and economical barriers, such as the people week awareness to CE.

\section{Survey on awareness of the circular economy among the younger generation}

In order to test the level of knowledge, the mentality of Czechs about $\mathrm{CE}$, their attitude to the environment, ecoinnovation and eco-friendly development a brief study was conducted during the end of February 2019. The representatives of the generation, born at the turn of the millennium (students) have been chosen as the respondents. This segment either enters or will enter into productive life in the next few years and will spend at least 40 years within the environment, what they can protect today, or they should learn how to protect and create it for tomorrow's future.

A short (about 10 questions) questioner was proposed. The total number of respondents was 137. To the direct question of: 1) "whether they have an awareness of the circulating economy?" the overwhelming majority replied that they have not. To the task to "find the tree typical definitions of CE" or "give simply 3 typical words characterizing this term" only three respondents answered closed to this topic! The attitude or practical behaviour, responding to environmental protection were more favourable. Less than $60 \%$ of respondents admitted that they are "partly interested in this topic"; $40 \%$ answered "very often interested in this subject", three respondents admitted that they are dedicated to this topic in their research and practical work. To the question of "sorting the waste", $2 / 3$ of the respondents sort the paper and plastic separately, 1/3 do sorting partially and episodically. Less favourable is the situation in sorting of rags and biowaste. About $1 / 3$ of respondents answered that they fully sort the rags and bio-waste; others have applied for partial sorting, either rags or bio-waste. To the question of sorting the battery and drainage of retired electrical appliances into electrical waste containers, about $50 \%$ of the respondents answered that they make this sorting, while the other $50 \%$ only occasionally participate in this type of waste recycling. Positive opinions have brought respondents' replies to the removal of plastic bags, what are offering without charge in retail chains, while purchasing goods. The majority welcomes and likes paper bags, cups and cutlery: respondents' attitude towards the energy costs of operation and the service of lifetime of purchased goods: The majority of respondents pay attention to lifetime, rather than to energy operating costs, choosing the answers "surely, yes" and "rather yes". The majority of respondents $(79 \%)$ get the information about environmental protection from media (internet, television, print); $20 \%$ remember the subject from secondary school $1 \%$ from summer camps, etc. (Figure 1).

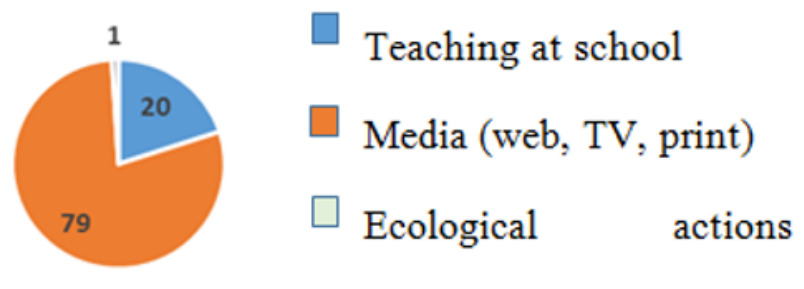

Fig. 1. Promoting environmental awareness (Source: authors'calculation).

The results of primary research indicate that the younger generation (particularly the group of the "20-22 years old" students) have limited awareness and poor understanding about the $\mathrm{CE}$ approaches, programs and business practice. The vast majority of respondents do not know anything about the circulate economy. The surveyed group of respondents' admitted that they gained from media the majority of information, but it come to them fragmentary and uncompleted. Moreover, they do not associate this information with the term circular economy, rather waste management. Their ecological awareness and behaviour are limited to the separation of paper, fewer rags and bio- and electrode waste; their shopping preferences are more determined by economic aspects than by environmental aspects. The results of survey brought us to the conclusion that environmental education, including the circular economy, has failed in previous education (primary and secondary school). On the other hand, the positive shifts are recorded in the Czech Republic in the field of sorting and separation domestic (communal) waste.

\section{Conclusions}

The choice and the targets of decarbonisation strategies in Europe will affect, and in turn will be affected by, the economic strategies of other countries. However, for many countries and giant corporations focusing on the extraction, processing and distribution of fossil fuels, there is no desirable trend to reduce them in the energy mix there is no synergetic effect. Laggard states not only do little to address climate change within their own boundaries but also actively impede efforts at federal climate change policies.

Scholars, regulators, and market participants all recognize that energy markets, in their current form, do not incentivize the rapid decarbonization of the electricity sector necessary to respond to climate change, thereby forcing states to act on their own. The primary problem confronting state climate change policy today is not only the underappreciated "social nature" of decarbonisation. The bigger problem is the fact that a good many citizens and state governments deny the existence of climate change and refuse to do much of anything to promote decarbonisation.

Advances in power-system integration are that renewable power already has a strong business case, but achieving its potential requires additional efforts in innovation for systems integration. Support for a portfolio of options for the end-use sectors is that 
effective support requires a combination of energy, technology breakthroughs, and sector-specific global agreements.

The following elements should be included in a policy framework for the energy transition. Innovation and innovation decisions in all spheres of economic policy and aspects of life are crucial for zero -carbon and zero-waste solutions. Leveraging synergies between innovations across all sectors and components of the system, and involving all actors, is important. Innovations in technology should be pursued equally assiduously as they are in enabling infrastructure and sector coupling, business models, market design, finance instruments, and policy frameworks. International cooperation on innovation for clean energy should be run after, taking advantages of relevant existing and introducing of new innovative platforms.

A circular economy improves resource efficiency and can therefore increase economic growth in a long-term sustainable manner. The way we deal with materials determines a large part of the greenhouse gas emissions. The circular economy is a resilient and climate-resistant economy, a new fiscal and legal framework is necessary for the transition to a circular low waste and low-carbon economy.

\section{References}

[1] BP Statistical Review of World Energy,68th edition, June 2019. https://www.bp.com/content/dam/bp/businesssites/en/global/corporate/pdfs/energyeconomics/statistical-review/bp-stats-review-2019-fullreport.pdf. Accessed 5 June 2019

[2] Eren Cifci and Matthew E. Oliver . Reassessing the Links between GHG Emissions, Economic Growth, and the UNFCCC: A Difference-in-Differences Approach. School of Economics, Georgia Institute of Technology, 223 Bobby Dodd Way, Atlanta, GA 30332, USA Sustainability 2018, 10(2), 334. https://doi.org/10.3390/su10020334

[3] Global Environment Outlook. GEO-6. Healthy Planet, Healthy People. United Nations Environment Programme. Sixth Edition, Cambridge University Press, 2019.https://content.yudu.com/web/2y3n2/0A2y3n3/GE O6/html/index.html?refUrl=https $\% 253 \mathrm{~A} \% 252 \mathrm{~F} \% 252 \mathrm{Fw}$ ww.unenvironment.org\%252Fresources $\% 252$ Fglobalenvironment-outlook-6. Accessed 15 June 2019

[4] United Nations. Framework Convention on Climate change. Summary of the Paris Agreement. https://unfccc.int/process-and-meetings/the-paris-

agreement/the-paris-agreement. . Accessed 12 June 2019

[5] European Comission:2050 long-term strategy, 28 November 2018. https://ec.europa.eu/clima/policies/strategies/2050_en. Accessed 15 June 2019

[6 ] Stern, Nicholas, A Blueprint for a Safer Planet. Bodley Head, 2009.

[ 7] Baum, Sr., Rudy M. "Future Calculations: The first climate change believer". Distillations. 2 (2): p.3839. Retrieved 22 March 2018.
[8] Brian Kahn. Earth's CO2 Passes the 400 PPM Threshold-Maybe Permanently. Climate Central. Journal Scientific American on September 27, 2016.

[9] World Meteorogical Organization: WMO presence on UNdata

(a data access system to UN databases), 2019. http://www.wmo.int/datastat/wmodata_en.html Accessed 5 June 2019

[10] United Nations Climate Change Conference, COP24 Katowice.http://www.cop24.katowice.eu1. Accessed 5 June 2019.

[11] BP Statistical Review of World Energy, 68th edition, 2019

[12] World Energy Outlook: Executive Summary. International Energy Agency, OECD/ EA, 2018.https://webstore.iea.org/download/summary/190?fi leName=English-WEO-2018-ES.pdf.

.[13] Andrews P. REUTERS: Zero by 2050: How the world's economy has planned to battle climate change,

2018.

https://www.weforum.org/agenda/2019/07/zeroemissions-target-climate-change-impact/12.Accessed 5 june 2019

[14] McKinsey Global Energy perspective: Reference case, January 2019https://www.mckinsey.com/ /media/McKinsey/Ind ustries/Oil\%20and\%20Gas/Our\%20Insights/Global\%20 Energy\%20Perspective\%202019/McKinsey-EnergyInsights-Global-Energy-Perspective-2019_ReferenceCase-Summary.ashx ]. Accessed 5 june 2019

[15] Global Energy \& CO2 Status Report. The latest trends in energy and emissions in 2018. https://www.iea.org/geco/Accessed 5 june 2019

[16] OECD. International Energy Agency. Update on recent progress in reform of inefficient. 2nd Energy Transitions Working Group Meeting Toyama, 18-19 April 2019.https://www.oecd.org/fossilfuels/publication/OECD-IEA-G20-Fossil-Fuel-

Subsidies-Reform-Update-2019.pdf. Accessed 5 june 2019

[17] Hone D. Carbon capture and use - how climate friendly is it? Energy Post, March 2017

[18] Directive 2018/2002 of the European Parliament and of the Council on energy efficiency, see: https://eurlex.europa.eu/legal-

content/CS/TXT/HTML/?uri=CELEX:32018L2002Acce ssed 5 june 2019

[19] Share of renewable energy in gross final energy consumption by sector//Source of data: Eurostat, 2018.

https://ec.europa.eu/eurostat/databrowser/view/sdg_0 7 40/CustomView_1/bar?lang= Accessed 5 june 2019.

[20] Report: The circularity gap, 2018. https://www.circularity-gap.world/Accessed 5 june 2019.

[21] Hyndman M., Green C. 2th inconvenient truth, 2019.

https://www.mcgill.ca/economics/files/economics/a_2nd _inconvenient_truth.pdf. Accessed 5 June 2019.

[22] Plastic Waste: a European strategy to protect the planet, defend our citizens and empower our industries// European Commission// Press release, Strasbourg, January 2018.https://europa.eu/rapid/press-release_IP18-5_en.htmAccessed 5 June 2019. 